Коваленко I. Пелагогічні основи професійної орієнтації учнівства ...

УДК 331.548

DOI https://doi.org/10.24919/2308-4863/34-3-34

Ія КОВАЛЕНКО,

orcid.org/0000-0002-4372-7598

здобувач кафедри педагогіки

Криворізького держсавного педагогічного університету

(Кривий Ріг, Дніпропетровська область, Україна) iakovalenko26@gmail.com

\title{
ПЕДАГОГІЧНІ ОСНОВИ ПРОФЕСІЙНОЇ ОРІЕНТАЦІЇ УЧНІВСТВА ЯК НАУКОВА ПРОБЛЕМА ДИСЕРТАЦІЇ П. І. ШЕВЧЕНКА
}

\begin{abstract}
Статтю присвячено узагальненню науково-педагогічного спадку Павла Івановича Шевченка щуодо проблеми професійної орієнтації учнів старших класів загальноосвітньої школи на робітничі професї гірничорудної та металургійної галузей. Констатовано втрату учнівською молоддю інтересу до робітничих спеціальностей, які становлять основу економічного розвитку держави, визначено наявність аналогічної проблеми в попередні десятиліття ХХ століття, на основі аналізу кандидатської дисертації П. І. Шевченка (керівник відділу освіти виконкому Криворізької міської ради народних депутатів у 60-70-х роках XX століття, відмінник освіти, заслужений вчитель Украӥнської Радянської Сочіалістичної Республіки, ректор Криворізького державного педагогічного інституту/університету з 1979 по 2000 рік) визначено ефективні напрями профорієнтаційної роботи з учнівською молоддю. Доведено, щчо практична значущість дослідження П. І. Шевченка полягала в тому, щзо автор розробив $і$ запровадив у практику роботи шкіл $і$ органів народної освіти комплексну систему професійної орієнтації учнів на гірничорудні і металургійні професії. Викладене вище дозволяє констатувати, щзо сучасна організація якісної профорієнтаційної роботи неможлива без урахування досвіду педагогів-практиків, учених, чий творчій доробок має бути врахований у сучасних умовах. Попри те, щзо вимоги до робітників гірничорудної $i$ металургійної галузей із часу наукової та практичної діяльності Павла Івановича Шевченка зазнали значних змін, оскільки змінилися технології видобутку та виробництва металу, знання основ ичих проиесів залишаються необхідним базисом у становленні фахівия зазначеної сфери. Необхідною залишається і системна підготовка молоді до вибору робітничої професії. Ще в 70-ті роки ХХ століття П. І. Шевченко наголошував на невідповідності між професійними намірами учнів та реальними потребами народного господарства в робітничих кадрах. Ця невідповідність спостерігається $і$ зараз. Тож поради вченого щзодо організації системної позашкільної роботи, налагодження у визначеному напрямі зв'язку між школою та родиною; поширення практики шефства виробничих колективів над иколами та координачія зусиль щодо профорієнтаиії на державному рівні залишаються актуальними. Крім того, наголошено, щзо сучасне тлумачення поняття «профрільна підготовка» практично цілком відповідає тим науковим засадам, які були сформульовані в кандидатській дисертачії П. І. Шевченка.

Ключові слова: П. І. Шевченко, профорієнтачійна робота, робітничі професії, кандидатська дисертація, народне господарство, промислові виробництва.
\end{abstract}

Iia KOVALENKO, orcid.org/0000-0002-4372-7598 Candidate at the Department of Pedagogy Kryvyi Rih State Pedagogical University (Kryvyi Rih, Dnipropetrovsk region, Ukraine) iakovalenko26@gmail.com

\section{PEDAGOGICAL FUNDATIONS OF PROFESSIONAL ORIENTATION OF STUDENTS AS A SCIENTIFIC PROBLEM OF PAVLO SHEVCHENKO'S DISSERTATION}

This article is devoted to the generalization of the scientific and pedagogical heritage of Pavlo Shevchenko on the problem of professional orientation of high school students to the working professions of mining and metallurgical industries. It is concluded that young people have lost interest in working professions, which form the basis of economic development of the state, determined that a similar problem was in the previous decades of the XX century, and based on the analysis of $P$. Shevchenko's candidate's dissertation (who was the head of the education department of the executive committee of the Kryvyi Rih City Council of People's Deputies in the 60's and 70's of the XX century, excellent education, honored teacher of the USSR, rector of the Kryvyi Rih State Pedagogical Institute / University from 1979 to 2000) identified effective areas of work with student youth on professional orientation. It is proved that the practical significance of $P$. Shevchenko's research was that he developed and introduced into the practice of schools and public education bodies a complex system of professional orientation of students to mining and metallurgical professions. This material allows us to conclude that the modern organization of quality career guidance work can not exist without taking into account the experience of teachers, practitioners, scientists in modern conditions. Professional requirements for workers in the mining and metallurgical industries have changed since the scientific and practical activities of Pavel Shevchenko, because the 
technology of mining and production of metal has changed, but knowledge of the basics of these processes remains a necessary basis for becoming a specialist in mining and metallurgy. Thus, systematic training of young people to choose a working profession remains necessary. In the 70's of the XX century P. Shevchenko emphasized the discrepancy between the professional intentions of students and the real needs of the national economy in the workforce. This discrepancy now exists. The scientist gave advice on the organization of systematic extracurricular activities, establishing a connection between school and family in a certain direction; dissemination of the practice of mentoring production teams over schools and coordination of efforts for career guidance at the state level, which remain relevant today. In addition, we emphasize that the modern interpretation of the concept of specialized training, almost completely corresponds to the scientific principles that were formulated in the dissertation of P. Shevchenko.

Key words: P. Shevchenko, career guidance work, working professions, candidate's dissertation, national economy, industrial productions.

Постановка проблеми. Людська праця і суспільне виробництво - основа устрою будь-якого суспільства, оскільки є рушійною силою його розвитку. Тому одним із головних напрямів теоретико-практичного дискурсу нинішньої педагогіки є проблеми організації та змісту підготовки кваліфікованих фахівців, забезпечення якісної системи профорієнтаційної роботи. Сучасна тенденція підвищення ролі інтелектуальної праці в комп'ютеризованому суспільстві призвела до суттєвих змін у попиті на професії. За даними Міністерства фінансів України, у 2020 р. більш затребуваними є IT-фахівці (програмісти, розробники програмного забезпечення, QA-інженери, спеціалісти 3 кібербезпеки тощо). Також існує стабільний попит на менеджерів із реклами, менеджерів iз продажу, HR-менеджерів. Від них вимагаються вміння швидко навчатись, концентруватись, вільно володіти англійською технічною мовою, уміння професійно спілкуватись із клієнтами, сприяти збільшенню обсягів продажів товарів або послуг, уміти вести документацію, володіти психологічними знаннями, коли працюють із персоналом, прийомами підвищення мотивації працівників, уміти проводити співбесіди й оцінювання робітників, інші компетентності. Очевидно, що за таких умов робітничі професії не викликають зацікавленості сучасної молоді, яка, на жаль, формується в умовах суспільства споживання.

Сучасні дослідники звертають увагу на зміни в ціннісних пріоритетах молоді під час вибору професії. Зокрема, А. П. Фрадинська зазначає: «Ще кілька десятиліть тому вибір майбутньої спеціальності визначався передусім тим, у якій частині країни людина народилася та виросла. У цьому питанні велику роль відігравали культурні та історичні традиції, а також суспільні потреби тієї чи іншої громади» (Фрадинська, 2010: 135). Нині у своєму виборі професії молодь орієнтується на інші чинники: престижність праці та матеріальна вигода. Інші чинники, як-от бажання займатися конкретно визначеною діяльністю; прагнення бути корисним людям, суспільству, є бажаними, проте не завжди реальними мотиваційними складниками професійного самовизначення. Т. А. Каткова й О. І. Титаренко в результаті проведеного аналізу впливу соціальних стереотипів молоді на професійний вибір констатують, що найбільш привабливими для молоді $є$ професії юриста та менеджера, на другому місці уподобань - професії програміста, журналіста, актора і вченого. «Протилежну позицію щодо самоідентифікації займають «продавець» і «слюсар», що не мають, на думку старшокласників, соціальних перспектив» (Каткова, Титаренко, 2019). Очевидно, що робітничі професії гірничої і металургійної галузі в Україні втратили суспільний престиж, а зацікавленість молоді у здобутті професійно-технічної освіти $\epsilon$ критично низькою. Зважаючи на те, що металургійна та гірничодобувна галузі - це безперервне виробництво 3 винятково складними, шкідливими та небезпечними умовами. Проблема залучення молоді на виробництво (зокрема, металургійне) - це не лише проблема сьогодення, педагогічна думка і сучасності, і минулого пропонує і пропонувала свої шляхи її розв'язання.

Аналіздосліджень. Упродовжостаннього десятиріччя із цієї проблеми були опубліковані дослідження Н. А. Дученко, О. М. Пильтяй, О. Г. Пономаренко, А. П. Фрадинської, В. Б. Харламенко. У них учені висвітлюють сучасні проблеми в підготовці учнів шкіл до вибору професії. Т. А. Каткова й О. І. Титаренко у своїй роботі подають аналіз стереотипів поведінки сучасної молоді, їхній вплив на формування професійних уподобань.

Мета статті - узагальнити науково-педагогічний спадок Павла Івановича Шевченка щодо проблеми професійної орієнтації учнів старших класів загальноосвітньої школи на робітничі професії гірничорудної та металургійної галузей.

Виклад основного матеріалу. Ідеї впровадження педагогічних основ профорієнтації в систему роботи загальноосвітніх і позашкільних закладів розвивав Павло Іванович Шевченко, керівник відділу освіти виконкому Криворізької міської ради народних депутатів у 60-70-х рр. 
XX ст., відмінник освіти, заслужений вчитель Української Радянської Соціалістичної Республіки, ректор Криворізького державного педагогічного інституту/університету з 1979 по 2000 р., який у своїй практичній та науковій роботі відобразив найбільш актуальні проблеми свого часу. Звертаємо увагу і на те, що особливості промислового виробництва Криворізького регіону (розвиток гірничої і металургійної галузей) актуалізували питання професійної орієнтації учнів старших класів загальноосвітніх шкіл на гірничорудні і металургійні професії.

Предметом нашого аналізу стала дисертаційна праця П. І. Шевченка «Педагогічні основи професійної орієнтації учнів старших класів загальноосвітньої школи на гірничорудні та металургійні професії» («Педагогические основы профессиональной ориентации учащихся старших классов общеобразовательной школы на горнорудные и металлургические профессии») 1978 р., для написання якої був використаний особистий досвід ученого-практика за 13 років роботи завідувачем Криворізького міськвно і члена комісії із трудових ресурсів при міськвиконкомі.

Передусім у своїй роботі науковець коментує опитування, яке було проведено серед старшокласників. Результати показували, що після закінчення восьмих і десятих класів до професійно-технічних училищ підуть навчатись $45-46 \%$ підлітків, у середні спеціальні навчальні заклади - 17\%, у вищі заклади освіти - 9-10\% випускників. Без професійної освіти планують працювати 27-29\% учнів (Шевченко, 1978: 5). Павло Іванович Шевченко у своїй роботі наголошує, що головне завдання профорієнтаційної роботи полягає в тому, щоби допомогти молодій людині усвідомлено обрати професію, визначити свій життєвий шлях, оскільки професійне самовизначення має сприяти досягненню оптимальної відповідності між здібностями і зацікавленнями, можливостями втілення професійних прагнень залежно від попиту народного господарства на різні види праці (Шевченко, 1978: 6). Уважаємо, що можливості цього поєднання залишаються актуальними і нині, оскільки відкривають шлях до вибору індивідуальної траєкторії професійного розвитку 3 урахуванням і орієнтацією на суспільні потреби.

Павло Іванович під час проведення аналізу педагогічних досліджень у галузі професійної орієнтації та досвіду роботи загальноосвітніх шкіл і позашкільних навчальних закладів наголошував на виключній ролі трудових колективів шефських підприємств у професійному визначені учнів, зазначав позитивний вплив індивідуаль- ного або колективного наставництва. Він пише, що професійну орієнтацію варто розглядати як складову частину навчально-виховного процесу. Розроблення науково-педагогічного підгрунтя професійної орієнтації підвищує ефективність професійного становлення молоді. Участь старшокласників у практичній роботі сприяє стійкому професійному зацікавленню (Шевченко, 1978: 6). На жаль, цей аспект в умовах ринкової економіки втрачає свою актуальність, хоча, безумовно, мав би бути дієвим.

Також вивчав Павло Іванович досвід організації профорієнтаційної роботи в закордонних країнах. Він зауважує, що в Болгарії в 70-х. pp. ХX ст. працювала Центральна комісія із професійної орієнтації, яка розробляла вимоги до кадрового забезпечення підприємств і організацій країни, методологію роботи із профорієнтації та їі форми. У Польщі існувала Державна система професійної орієнтації школярів. Дітей відбирали до спеціалізованих шкіл. У Німецькій Демократичній Республіці профорієнтаційні питання вирішувала Державна планова комісія. У країнах розвиненого капіталізму існували Спеціальна загальнодержавна служба та приватні служби із професійної орієнтації. Отже, і в нинішніх умовах такого роду робота мала б бути продовжена централізовано.

У результаті вивчення наукової і педагогічної літератури того часу Павло Іванович констатував, що педагогічні основи професійної орієнтації учнів на гірничорудні і металургійні професії не було розроблено. Хоча у країні (Радянський Союз) інтенсивно розвивалась чорна металургія, і в цій галузі працювало (на 1975 р.) загалом 3,5 млн осіб, лише у Кривому Розі - 200 тисяч осіб, що становило на той час половину працюючого населення міста (Шевченко, 1978: 9). Гірничорудні і металургійні професії вимагають від робітника значної фізичної витримки, вимушеного нетипового положення тіла під час роботи, на нього впливає вібрація від пневматичних інструментів і механізмів, впливає робота під землею, біля доменних і сталеплавильних печей, існує вплив забрудненого повітря, нервове та психічне навантаження й інші чинники. Для робітників цієї сфери встановлено вік із 20 років, цей факт ускладнює роботу педагогічних колективів, промислових підприємств, організацій iз формування професійного інтересу учнівства до цих професій, оскільки вік закінчення школи 17 років. До того ж через означені вище складності професій батьки не радять дітям обирати їх.

Ціллю свого дисертаційного дослідження Павло Іванович обрав розроблення й обгрунтування педагогічних основ професійної орієнтації 
учнів на гірничорудні і металургійні професії, розроблення рекомендацій для практичних робітників шкіл.

Основними завданнями дослідження були: з'ясування об'єктивних можливостей профорієнтаційної роботи на гірничорудні і металургійні професії у процесі вивчення основ наук; виявлення чинників, які впливають на вибір гірничорудних і металургійних професій учнями, у процесі організації позаурочних занять; дослідження навколишнього соціального оточення, його вплив на формування професійної спрямованості учнів на гірничорудні і металургійні професії; обрання шляхів і засобів підвищення ефективності профорієнтації на гірничорудні і металургійні професії. Відповідно до теми був визначений предмет дослідження, а саме орієнтація учнів старших класів на гірничорудні і металургійні професії у процесі організації навчально-виховного процесу у школі та в позашкільній діяльності (Шевченко, 1978: 41). Окреслений науковий апарат дослідження свідчить про глибину опрацювання науковцем-практиком проблеми, а отже, дозволяє говорити про ï актуальність та відповідність сучасним вимогам до наукових досліджень.

Проведене дослідження доводить, що на вибір гірничорудних і металургійних професії впливають такі чинники, як: комплексний виховний процес протягом всього терміну навчання у школі, розвиток і формування пізнавальних і професійних інтересів і схильностей у процесі вивчення основ наук на базі політехнічного навчання, шкільні громадські організації, система виховних заходів впливу в позаурочній роботі, участь у профільних і технічних гуртках, клубах, факультативних заняттях, у практичній трудовій діяльності, вплив родини, шефських трудових колективів, соціальне середовище, засоби масової інформації тощо. Важливі спрямованість особистості, система спонукань, яка визначає вибір професії та діяльності людини. Педагогічний колектив водночас повинен бути обізнаний в обгрунтованому прогнозі потреб у робітничих кадрах конкретного економічного регіону, мати систему знань про професії, знати зацікавлення і схильності учнів, володіти методикою їх вивчення, уміти розроблять систему цілеспрямованих навчально-виховних заходів педагогічного колективу і громадських організацій, спрямованих на формування пізнавальних і професійних інтересів і схильностей учнів до гірничорудних і металургійних професій (Шевченко, 1978: 167-168).

Павло Іванович підкреслював педагогічний аспект професійної орієнтації та наголошував на важливості вивчення змісту, форм і методів під- вищення ефективності співпраці 3 навчальновиховної роботи школи із сім'єю, промисловими підприємствами і громадськістю 3 метою підготовки молоді до усвідомленого вибору професії. Важливими умовами наукової організації профорієнтації, на думку вченого, є: усебічне вивчення учнів, виявлення і розвиток інтересів, схильностей, фізичних і психологічних можливостей; знайомство учнів із різними галузями народного господарства, найбільш поширеними професіями даного регіону; виховання стійкого інтересу до гірничорудних і металургійних професій; допомога учням у набутті вмінь та навичок для виконання різних трудових операцій, як у школі, так i в умовах виробництва, пов'язаних із їхніми професійними вподобаннями; формування всебічно розвиненої особистості; розкриття громадської значущості робітничих професій; знайомство учнів із вимогами до гірничорудних і металургійних професій та характером роботи; консультування учнів щодо того, де саме можна опанувати відповідні спеціальності; аналіз адаптації випускників шкіл на підприємствах. Зокрема, у школах, де проводили експеримент, $27 \%$ випускників працевлаштувались на роботу за спеціальностями гірничорудної і металургійної галузі і продовжували навчання за цим профілем, 44\% учнів, які брали участь у факультативних заняттях із фізики, хімії та математики, 54\%, які відвідували професійні і технічні гуртки (Шевченко, 1978: 169).

П. І. Шевченко також наголошував на важливості підготовки молоді до життя і до професійного самовизначення, передумови цього вбачав в політехнічному підході до навчання. Уважав, що до професійної орієнтації мають також долучитися вчителі-предметники. Аналіз змісту програмного матеріалу учнів старших класів із хімії, фізики, математики, географії, суспільствознавства, історії, трудового навчання, проведений ученим, свідчить про те, що у процесі викладання основ наук учитель має можливість формувати професійні спрямування учнів на гірничорудні i металургійні професії.

Ефективною також визнавалася позашкільна освіта, зокрема робота гуртків «Юний гірник», «Юний металург», технічні факультативи. Педагог наголошував на необхідності проводити практичні, лабораторні роботи й екскурсії на підприємства, вести психологічну підготовку учнів до праці в зазначеній сфері, формувати практичні навички і вміння, необхідні для гірничорудних і металургійних професій. Соціальне оточення, матеріальне і духовне оточення мають вирішальний вплив на професійну спрямованість на гір- 
ничорудні і металургійні професії, тому важливою ланкою роботи шкільних колективів було проведення спільних заходів шкіл і виробництв. Під час проведення профроботи з батьками учнів ефективними виявились бесіди на теми професійного самовизначення дітей, запрошення батьків до профроботи з учнями у школі.

В останній частині свого дослідження Павло Іванович запропонував рекомендації для підвищення ефективності професійної орієнтації, a саме пропонував: створити міжвідомчі ради для координації всіх напрямів профорієнтації і роботи відповідних служб, які працюють над підготовкою молоді до вибору професії; переглянути зміст курсу педагогіки в закладах вищої освіти 3 метою глибшого висвітлення наукових основ системи профорієнтації; увести спецкурс у педагогічних інститутах, під час якого теоретично, психологічно і практично готувати вчителів до проведення профорієнтаційної роботи; розробити класифікацію професій та скласти професіограми основних робітничих професій; розробити практичні рекомендації і посібники із психологічних основ і методів активізації професійного самовизначення учнями; розробити прогноз потреб у трудових ресурсах у країні і за галузями, розробити рекомендації з підвищення престижу робітничих професій; переглянути зміст навчальних предметів, передбачити використання в ньому профорієнтаційного матеріалу (Шевченко, 1978: 174). Очевидно, що частина рекомендацій Павла Івановича має те чи те втілення в подальшому розвитку освіти, проте переважна частина окресле- них вище рекомендацій може бути використана в сучасних умовах розвитку освіти, в аспекті організації професійної орієнтації учнів з орієнтацією на потреби особистості та суспільства.

Висновки. Викладене вище дозволяє констатувати, що сучасна організація якісної профорієнтаційної роботи неможлива без урахування досвіду педагогів-практиків, учених, чий творчий доробок має бути врахований у сучасних умовах. Попри те, що вимоги до робітників гірничорудної і металургійної галузей із часу наукової та практичної діяльності Павла Івановича Шевченка зазнали значних змін, оскільки змінилися технології видобутку та виробництва металу, знання основ цих процесів залишаються необхідним базисом у становленні фахівця зазначеної сфери. Необхідною залишається і системна підготовка молоді до вибору робітничої професії. Ще в 70-ті pp. XX ст. П. І. Шевченко наголошував на невідповідності між професійними намірами учнів та реальними потребами народного господарства в робітничих кадрах. Ця невідповідність наявна і зараз. Отже, поради вченого щодо організації системної позашкільної роботи, налагодження у визначеному напрямі зв'язку між школою та родиною; поширення практики шефства виробничих колективів над школами, координації зусиль щодо профорієнтації на державному рівні залишаються актуальними. Крім того, наголошуємо, що сучасне тлумачення поняття «профільна підготовка» практично цілком відповідає тим науковим засадам, які були сформульовані в кандидатській дисертації П. І. Шевченка.

\section{СПИСОК ВИКОРИСТАНИХ ДЖЕРЕЛ}

1. Дученко Н. А. Профорієнтаційна робота у школі. Таврійський вісник освіти. 2016. № 1 (53). С.152-159.

2. Каткова Т. А., Титаренко О. I. Вплив соціальних стереотипів молоді на професійний вибір. URL: http://www.tpsp-journal.kpu.zp.ua/archive/5_2019/part_1/18.pdf.

3. Пильтяй О. М. Сучасні тенденції та проблеми у підготовці учнів до вибору професії в навчальному процесі. Молодий вчений. 2020. № 5 (81). С. 400-406.

4. Пономаренко О. Г. Сучасні методи та форми профорієнтаційної роботи в Україні. Актуальні проблеми педагогіки, психології та професійної освіти. 2015. URL: http://journals.uran.ua/apppfo/article/view/55463/51645.

5. Фрадинська А. П. Свідомий вибір професії як головна проблема сучасної молоді. Збірник наукових праць Хмельницького інституту соиіальних технологій Університету «Украӥна». 2010. № 2. С. 135-139.

6. Шевченко П. И. Педагогические основы профессиональной ориентации учащихся старших классов общеобразовательной школы на горнорудные и металлургические профессии : дис. ... канд. пед. наук: 13.00.01. Киев, 1978. $174 \mathrm{c}$.

\section{REFERENCES}

1. Duchenko N. Proforiientatsiina robota v shkoli. [Career guidance work at school]. Taurian Bulletin of Education, 2016, № 1 (53), pp.152-159 [in Ukraine].

2. Katkova T. Tytarenko O. Vplyv sotsialnykh stereotypiv molodi na profesiinyi vybir. [The influence of social stereotypes of young people on professional choice]. 2019. URL: http://www.tpsp-journal.kpu.zp.ua/archive/5_2019/ part_1/18. pdf. [in Ukraine].

3. Pyltiai O. Suchasni tendentsii ta problemy u pidhotovtsi uchniv do vyboru profesii v navchalnomu protsesi. [Current trends and problems in preparing students to choose a profession in the educational process]. Young Scientist, 2020, № 5 (81), pp. 400-406. [in Ukraine]. 
4. Ponomarenko O. Suchasni metody ta formy proforiientatsiinoi roboty v Ukraini. [Modern methods and forms of career guidance work in Ukraine]. Current issues of pedagogy, psychology and vocational education. 2015. URL: http://journals.uran.ua/apppfo/article/view/55463/51645 [in Ukraine].

5. Fradynska A. Svidomyi vybir profesii yak holovna problema suchasnoi molodi. [Conscious choice of profession as the main problem of modern youth]. Collection of scientific works of Khmelnytsky Institute of Social Technologies, University "Ukraine", 2010, № 2, pp. 135-139 [in Ukraine].

6. Shevchenko P. I. Pedagogicheskie osnovy professional'noj orientacii uchashchihsya starshih klassov obshcheobrazovatel'noj shkoly na gornorudnye i metallurgicheskie professii: [Pedagogical foundations of professional orientation of high school students in mining and metallurgical professions] dissertation of the candidate of sciences : 13.00.01. - K., 1978, 174 p. [in Russian]. 